\title{
Özel Dosya: Toplumsal Cinsiyet ve Şiddet Sayı Editörlerinden
}

\author{
Başak Tuğ Onaran, Gülhan Balsoy, Nazan Haydari Pakkan
}

Modern devlet tahayyülünün “savaşan erkek” ve “doğuran kadın” arasında kurduğu eşitsiz ilişki, devlet ile vatandaşları arasındaki ilişkiyi de eril devlet/eril vatandaş ile korunan/kollanan yahut dövülen/öldürülen kadın arasındaki tahakküm ilişkisi dışında tanımlamaya çok fazla izin vermiyor. Bu tahakküm ilişkisine başkaldıran feminist hareket ve LGBTİ+ aktivizmi, uzun yıllar süren mücadeleler sonucunda eril devletin ve vatandaşın kadınlara, eşcinsellere, translara uyguladığı ev-içi ve kamusal şiddeti görünür hale getirdiler. Feminist akademik çalışmalar ve feminist mücadele, toplumsal cinsiyete dayalı şiddetin tarihsel temellerini irdeleyerek birkaç ceza hukuku düzenlemesi ya da "pozitif ayrımcılık" ile çözülemeyecek olan yapısal özelliklerine dikkat çektiler. Böylece, toplumsal cinsiyet temelli şiddet bir ayrımcılık ve insan hakları meselesi olarak tartışmaya açıldı.

Fakat neo-liberalizm, muhafazakarlık ve sağ popülizmin yükseldiği küresel dünyada, mücadelesi verilen ve kazanılan "haklar" bir şiddet sarmalında olduğumuz aşikâr. Nitekim Kadına Karşı Her Türlü Ayrımcılığın Yok Edilmesi Sözleşmesi (CEDAW-1979) ve Kadınlara Yönelik Şiddetin ve Ev-içi Şiddetin Önlenmesi için Avrupa Konseyi’nin hazırladı̆̆ı İstanbul Sözleşmesi (2011), Türkiye’nin de içinde bulunduğu birçok Avrupa ülkesi tarafından imzalanmışken sağ popülist iktidarlar son yıllarda bu sözleşmeleri reddetme yolunda adımlar atmaya başladı. Örneğin İstanbul Sözleşmesi'nde imzası olan Macaristan sözleşmeyi onaylamayı reddederken, Polonya ve Türkiye gibi onaylamış ülkeler sözleşmeden çekilmeyi tartışır hale geldiler. Bu da bizlere, kanunların ve sözleşmelerin toplumsal cinsiyet eşitliğinin tesisi açısından elzem ve bir o kadar da kırılgan olduklarını gösteriyor. Ayrıca, küresel dünyanın içinde bulunduğu iklim krizi ve Covid-19 krizi, toplumsal cinsiyet eşitliğini çeşitli şekillerde tehdit ederken, bu alandaki şiddeti de körükler hale geldi.

İstanbul Sözleşmesi'nden çekilmeye yönelik tartışmalardan yola çıkan bu özel sayı, çeşitli disiplinlerden ve alanlardan farklı yöntemsel yaklaşımları benimseyen katkılarla, toplumsal cinsiyet ve şiddet arasındaki ilişkiyi yakıcı güncel problemler ekseninden bir nebze olsun çıkararak, toplumsal cinsiyet eşitsizliklerinin ve şiddetin farklı tezahürlerini ve yeniden üretilme mekanizmalarını geniş bir tarihsel çerçevede incelemeyi amaçlıyor. Eşitsizlikler ve ayrımcılıklar arasında hiyerarşik bir ilişki kurulamayacak olsa da cinsiyet eşitsizliğinin şiddeti 
normalleştirme, sıradanlaştırma ve görünmez kılma potansiyeli yüksektir. Bu noktadan hareketle bu sayıda, şiddet ve toplumsal cinsiyet arasındaki ilişki, eşitsizlikleri besleyen sınıf, ırk, etnisite, yaş gibi diğer alanların şiddetle ilişkisinden ne kadar farklıdır, toplumsal cinsiyet eşitsizliği şiddeti ne ölçüde ve ne şekillerde besliyor gibi sorular üzerinden düşünmeye çalıştık.

Alev Özkazanç'ın toplumsal cinsiyet ve şiddet arasındaki zorlu ama zorunlu olmayan ilişkiye dair uyarıları, bu sayının ortaya çıkışındaki temel saikleri özetler nitelikte. Toplumsal cinsiyet eşitsizliği, cinsellik ve şiddet arasında tarihsel ve toplumsal olarak güçlü rabitalar yaratmış olsa da şiddeti cinsellikle sınırlamak ya da cinselliğin sınırlarını şiddet ekseninin ötesinde düşünememek feminist üretimi ve siyaseti kısıtlamaktan başka bir şeye hizmet etmeyecektir. Özkazanç’ın toplumsal cinsiyet eşitsizliğinin kuruluşunda şiddet ve cinsiyet arasındaki ilişkiyi kuramsallaştırmaları açısından Federici, Pateman ve MacKinnon'un çalışmalarına getirdiği eleştirel okumada göstermeye çalıştığı gibi, kapitalizmin cinsiyetçi işbölümü, liberalizmin evlilik akdi ile gerçekleştirdiği cinsel sözleşmesi ve modern toplumun şiddete dayalı heteroseksüel cinsel ilişkisi, cinsellik ve şiddet arasında kaçınılmaz ve özcü bir ilişkinin varlığından ziyade, toplumsal, ekonomik ve siyasi yapıların ve kurumların tarihsel şekillenişleriyle ilgilidir. Tam da bu sebeple, Özkazanç’ın da belirttiği gibi, toplumsal cinsiyeti kuran normlar ve kurumsal işleyişlerde, eşitsizlikleri yeniden üreten farklı tahakküm ve rıza ilişkilerini, gerektiğinde şiddetten ayırt ederek tarihsel bağlamları içinde incelemek içinde bulunduğumuz kritik dönemde de büyük bir önem taşıyor. Ancak bu şekilde topyekûncu ve indirgemeci bir toplumsal cinsiyete dayalı şiddet tanımından kurtulup, yine Özkazanç'ın işaret ettiği gibi, şiddete karşı farklı mücadele pratikleri ve araçları geliştirebiliriz.

Nitekim, Görüşler/Reflections bölümünde sorduğumuz sorulara karşılık olarak psikoloji, sosyoloji, iletişim ve ekonomi gibi farklı disiplinlerden gelen akademisyenlerin toplumsal cinsiyet temelli şiddeti ve İstanbul Sözleşmesi çevresinde çıkan tartışmaları kendi disiplinleri çerçevesinde değerlendirdikleri cevaplar Özkazanç’ın uyarısını doğrular nitelikte. $\mathrm{Bu}$ değerlendirmeler, hem şiddet ve toplumsal cinsiyet arasındaki ilişkinin farklı veçhelerini görmemizi sağlıyor, hem de farklı alanlarda yürütülmesi gereken çok boyutlu mücadele pratikleri ve araçları üzerine bize düşünme fırsatı veriyor. Örneğin, Yelda Yücel, İstanbul Sözleşmesi'nin “ekonomik şiddet”i kadına yönelik şiddet biçimleri arasında tanımlayarak, esasında kamu otoritelerini köklü bir ekonomik yeniden yapılandırmaya mecbur bıraktığını vurguluyor. Yani, iktisadi bir perspektiften bakıldığında ekonomik şiddeti de kapsar bir biçimde tanımlanan aile-içi şiddet bir kamu sorunu olarak ortaya çıkıyor. Dolayısıyla, Yücel'e göre aile-içi şiddete karşı feminist mücadele, kadınların eğitim ve işgücüne katılımı, insana yakışır iş koşullarının sağlanması, iş yerinde taciz ve kötü muameleyle mücadele gibi kamu politikalarını da içermek zorunda.

Sosyal psikoloji alanından gelen bir yaklaşımla Melek Göregenli, toplumsal cinsiyet eşitsizliğini, diğer eşitsizlikleri de doğuran ve meşrulaştıran bir tür olarak hiyerarşik sistemler içindeki en önemli eşitsizlik olarak tanımlıyor. Bu bağlamda, erkek egemen heteronormatif toplumsal cinsiyet ideolojilerinin ve toplumsal cinsiyete dayalı şiddetin, biyolojik değil ideolojik 
ve tarihsel bağlamları içinde bir iktidar meselesi olarak ele alınması gerektiğine vurgu yapıyor. İstanbul Sözleşmesi'ne verilen eril muhafazakâr tepkileri de böyle bir iktidar perspektifinden değerlendiriyor. Sosyolog Cenk Özbay da benzer bir biçimde, toplumsal cinsiyet temelli şiddetin, erkeklik icra etmek, erkekliği pekiştirmek ve "daha bir erkek olmak" üzerinden normalleştirildiğini söylemekle birlikte, bütün bu "performans” In erkeklerin kadınlar ve kendisini bu ikiliğin dışında tanımlayanlar üzerindeki tahakkümlerini kaybetmemek için verilen canhıraş bir çaba olduğunu belirtiyor. Disiplinler-arası bir alan olan iletişim çalışmalarını ele alan Nilüfer Timisi ise toplumsal cinsiyet ve şiddet ilişkisini, alanın tarihsel izleği içerisinde anaakım ve eleştirel yaklaşımlar çerçevesinde değerlendiriyor. Anaakım iletişim çalışmaları kamu güvenliği, maneviyat, ahlak, düzen, ailenin korunması gibi gerekçelerle toplumun genelinin, özellikle de çocuk ve gençlerin şiddet içeriğinden nasıl korunacağı konularına odaklanırken, eleştirel yaklaşımlar toplumsal cinsiyete dayalı şiddetin nasıl inşa edildiğini sorgulayarak ideolojik/simgesel işlevini sorunsallaştırıyor. Yeniden üretim alanı olarak medya toplumda görülen şiddetin yeniden üretilip olumlandığı, şiddet mağduru kadının bir kez daha mağdurlaştırıldığı ve hak ihlallerinin gerçekleştiği bir alan haline geliyor.

Görüşler/Reflections bölümünün devamı niteliğinde olan görüş kısmında iki çalışmaya yer veriyoruz. Birincisi, Hale Bolak Boratav'ın paylaştığı sosyal psikoloji alanına dair bir değerlendirme yazısı "Feminizm ve Psikoloji: Sıkıntılı bir İlişki". Psikoloji ve toplumsal cinsiyet arasındaki tarihsel olarak süregiden gerilimli ilişkilerin sorgulandığı bu yazıda Bolak Boratav, sosyal psikoloji alanında şiddetin ve toplumsal cinsiyetin ele alınışnın dönüşümüne dair bir açılım da sunuyor. Bu ilişkileri psikolojide kuram, yöntem ve uygulamalar, kadın ve toplumsal cinsiyet çalışmalarının gelişimi ve feminist psikologların ana-akım psikolojide var olma mücadeleleri ve farklı coğrafyalarda karşılaştıkları direnç açısından ele alıyor. Eleştirel kuram ve feminist çalışmaların psikoloji alanına katkılarını ve geleceğe yönelik temennilerini paylaşıyor.

Görüşler/Reflections bölümünde ikinci olarak, Pınar Uyan Semerci ve Emre Erdoğan'ın yürütmekte oldukları kutuplaşma projesi kapsamında tamamladıkları saha araştırmasında İstanbul Sözleşmesi'nin ve kadına yönelik şiddetin algılanışına dair bulguları paylaştıkları makalelerine yer veriyoruz. İstanbul Sözleşmesinden haberdarlık, toplumsal cinsiyet rolleri algısı, kadına yönelik şiddetin yaygınlığı, nedenleri ve sorumluları konularındaki algı ve bu alanlar arasındaki ilişki üzerine olan araştırma, İstanbul Sözleşmesi'nin toplumda nasıl algılandığının ötesinde veriler sunuyor bizlere. Kadına yönelik şiddetin yaygınlı̆̆ının neredeyse tüm kamuoyu tarafından paylaşıldığını gösteren araştırma, kadına yönelik şiddetin sebepleri arasında sayılan eğitimsizlik, ekonomik sorunlar ve cezaların uygulanmaması gibi faktörlerin ortadan kaldırılması yönünde toplumun yükümlülügü devlete verdiğini de göstermekte.

Refleksiyon ve görüş bölümlerinden ayrı olarak bu sayıda yer alan makalelerin cinsel taciz, aile içi şiddet, devlet şiddeti, gündelik şiddet gibi şiddet çeşitlerinin toplumsal cinsiyet ile olan yapısal ilişkisini gösterecek bir bütünlük teşkil ettiğini düşünüyoruz. Talin Suciyan'ın makalesi, bu sayıda amaçladığımız toplumsal cinsiyete dayalı şiddeti tarihsel bir 
perspektife oturtma çabasının dikkatli bir örneğini teşkil ediyor. Suciyan çalışmasında, 19. yüzyıl Osmanlı İmparatorluğu sınırlarında hukuki tanımlara hapsedildiğinde yalnızca "zina" olarak adlandırılacak gayri-meşru bir ilişkideki cinsel şiddet ihtimalinin, Ermeni cemaatinde var olan ensest tabusu çerçevesinde nasıl bir toplumsal ve hukuki sorun haline geldiğini ama aynı zamanda da üstünün kapatılmaya çalışıldığını gözler önüne seriyor. Çalışma, bize cinsel şiddet, zina ve ensest gibi olguların sınırlarının muğlaklığını ve bu muğlaklığın bugün olduğu gibi geçmişte de nasıl kadınlar aleyhine kullanıldığını gösteriyor.

Gülhan Balsoy'un makalesi, dayak ve sarkıntılık gibi kısıtlı şiddet biçimlerinden bu sayıda kastedilen geniş çerçevede tanımlanmış bir cinsel şiddet kavramına geçişte, Türkiye'deki feminist hareketin katkısını gözler önüne sererek toplumsal cinsiyete dayalı şiddet kavramının tarihsel yapı taşlarına işaret ediyor. Örneğin, Dayağa Karşı Dayanışma kampanyasının, yaratıcı bir feminist eylemlilik ve yazma pratiği ile aile-içi şiddet ile iktidar arasındaki ilişkiye dair feminist yöntem ve mücadele araçlarının geliştirilmesinde tarihsel bir öneme sahip olduğunu gözler önüne seriyor. Balsoy’a göre, Mor İğne kampanyası da kampanyanın yürütüldüğü dönemde tedavülde olan sarkıntılık, elleme, dokunma gibi kavramların yerine mağdurun görselleştirilmesini ortadan kaldırmaya çalışan ve bu şiddet biçimini politize etmeyi mümkün kılan cinsel taciz kavramının kullanılmaya başlanmasında önemli bir dönemeç niteliğinde olmuştur.

Bu dönüşümün kadına yönelik şiddet ve cinsel taciz konularının 1990lardan itibaren birer toplumsal sorun olarak giderek daha fazla gündeme gelmesindeki rolü kadar, Rabia Asya Dalkılıç'ın çalışmasında incelediği kamu politikalarının geliştirilmesinde de önemli bir rol oynadığı düşünülebilir. Dalkılıç, bu alanda var olan yazına bütüncül bir yaklaşım kazandırmayı ve politika üretici aktörlerin kadına yönelik şiddeti tanımlama, ele alma biçimlerini, ne tür politikalar oluşturduklarını ve bunların uygulanma biçimlerini değerlendiriyor çalışmasında. Makale Türkiye'de bu alandaki kurumsal çerçevenin tarihsel olarak gelişimini aktarmanın yanı sıra yasal düzenlemeleri, iştirak eden / inşa edilen kurumları da oldukça kapsamlı bir çerçevede inceliyor. Bu çalışmanın belki de en önemli katkısı, yasal ve kurumsal düzenlemeleri gündelik uygulamalarla karşılaştırarak yasal düzenlemelerde var olan ama uygulamada buharlaşan faaliyetleri bize apaçık gösteriyor olması.

Şiddetle mücadelede devlet dışı aktörleri düşünmenin önemini hatırlatan bir diğer katkı başka bir coğrafyadan geliyor. Satarupa Dasgupta Hindistan Kalküta bölgesindeki seks işçilerinin karşılaştığı zorlukları, direniş ve dayanışma biçimlerini seks iş̧̧ilerinin anlatıları üzerinden ele alıyor. Seks işçilerini çalışmanın öznesi olarak tanımlayarak kendi gerçekliklerinin iletişimsel inşasını nasıl kurduklarını inceliyor. Çalışma seks ticareti gibi yüksek oranda cinsiyetçiliğin olduğu bir iş kolunda çalışan, seks işçileri gibi yüksek oranda marjinalize edilmiş toplulukların kriminalizasyon, damgalama ve şiddet gibi engellerle dayanışma örneği göstererek nasıl başa çıktıklarını tartışıyor.

Bu noktada, Yeşim Mutlu ve Mehtap Tosun'un çalışması şiddete tam karşı eksenden, güvenlik çerçevesinden bakarak bize farklı bir perspektif sunuyor. Mutlu ve Tosun, güvenlik 
çalışmalarındaki eleştirel yaklaşımı izleyerek “insani güvenlik” kavramına odaklanıyor ve şiddet sarmalının en çok etkilediği gruplar olan kadınlar ve LGBTİ+'ların güvenlik/güvende hissetme algısını inceliyorlar. Mutlu ve Tosun'un işaret ettiği gibi güvenliğin her durumda geçerli olabilecek bir tanımını yapmak pek mümkün olmasa da güvenlikli bir hayat talebi, şiddetin her türlüsü ile özel alanda da kamusal alanda da karşılaşma ihtimalinin olmadığı bir duruma işaret eder. Oysa şiddet deneyimi, güvende olmanın anlamlarını da sarsar. Tam da bu nedenle şiddet deneyimlerinin bizzat bunu yaşamış olan kadın ve LGBT+'lar tarafından dillendirilmesi güvenliğin ne olduğu, nerelerde üretildiği ya da ihlal edildiği gibi konularda da önemli açılımlar sunmakta.

İvo Furman ve Ertuğrul Süngü ise, toplumsal cinsiyet temelli şiddetin ve eşitsizliğin yeniden üretildiği bir alan olarak internete odaklanıyor. Netnografi yönteminin uygulandığı bu araştırma, internet ortamının sunduğu etkileşim araçlarını kullanarak geliştirilmiş bir kolaboratif örgütlenme modeli olan Ekşi Sözlük sanal topluluğundaki faaliyetlerin gündelik hayattaki toplumsal cinsiyet eşitsizliğini yeniden üreten ve pekiştiren mekanizmalar haline gelişini tartışıyor. Özel mesaj iletileri ve forum benzeri kamusal alan pratikleri üzerinden biçimlenen sanal iletişim dinamiklerinin nasıl da kadınların tacize uğradığı, namus kavramının yeniden üretildiği, taciz ve yasaklamayı haklı çıkarmak için kullanıldığı araçlar haline geldiğinin altını çiziyor. Araştırma ayrıca sanal toplulukların cinsiyetçi söylemlerinin sorgulanıp tartışılmasına alan açacak uygulamaya yönelik somut öneriler sunuyor ve bu cinsiyetçiliği eleştirel olarak değerlendirebilen deneysel araştırmalara duyulan ihtiyaca da işaret ediyor.

Toplumsal cinsiyet ve şiddet konulu bu özel sayının, toplumsal cinsiyet eşitsizliklerinin ve toplumsal cinsiyete dayalı şiddetin çeşitli veçheleri ve saiklerini tartışmaya açarak bu alandaki şiddetin azaltılması yönünde katkıda bulunması en büyük arzumuz. Tabii ki İstanbul Sözleşmesi’nin uygulanması ve kadın cinayetleri ve homofobik şiddetin bitmesi yönünde söz söylemeye ve siyaset üretmeye devam ederek... Unutmayalım ki “İstanbul Sözleşmesi Yaşatır”! 